\title{
Non-state Sovereign Entrepreneurs and Non-territorial Sovereign Organizations
}

\author{
Jurgen Brauer ${ }^{1}$ and Robert Haywood ${ }^{2}$
}

February 2010

\begin{abstract}
We propose two new concepts, of non-state sovereign entrepreneurs and the nonterritorial sovereign organizations they form, and relate them to issues pertaining to state sovereignty, governance failures, and violent social conflict over the appropriation of the powers that accrue to states in modern international law. The concepts deal with the rise of transboundary non-state actors, as they impinge on and aim to supplement or supersede certain powers of state actors. We provide examples to show that non-state sovereign entrepreneurs and their organizations already exist. We are interested in their potential role in conflict transformation.
\end{abstract}

Keywords: entrepreneurship, non-state sovereign entrepreneur, non-state sovereign organization, non-governmental organization, conflict, war, civil war, violence, peace

JEL classification: F53, F55, H80, K33

Copyright (C) UNU-WIDER 2010

${ }^{1}$ James M. Hull College of Business at Augusta State University, Augusta, GA, email: jbrauer@aug.edu ${ }^{2}$ One Earth Future Foundation, email: bhaywood@OneEarthFuture.org

This study has been prepared within the UNU-WIDER project on Entrepreneurship and Development (Promoting Entrepreneurial Capacity), directed by Wim Naudé.

UNU-WIDER gratefully acknowledges the financial contributions to the project by the Finnish Ministry for Foreign Affairs, and the financial contributions to the research programme by the governments of Denmark (Royal Ministry of Foreign Affairs), Finland (Finnish Ministry for Foreign Affairs), Sweden (Swedish International Development Cooperation Agency—Sida) and the United Kingdom (Department for International Development). 


\section{Acknowledgements}

This paper was conceived while Brauer was the One Earth Future Foundation's research director. The views expressed here are ours and should not necessarily be ascribed to the Foundation. We thank Jeffrey French and Matthew Bunch for research and drafting assistance. By invitation, a version of this paper was delivered as a keynote address for the United Nations University's World Institute for Development Economics Research (UNU-WIDER) Project Workshop on Entrepreneurship and Conflict held at the International Conflict Research Institute (INCORE), University of Ulster, Londonderry, Northern Ireland, 20-21 March 2009. We thank our hosts and workshop participants for their interest and comments.

The World Institute for Development Economics Research (WIDER) was established by the United Nations University (UNU) as its first research and training centre and started work in Helsinki, Finland in 1985. The Institute undertakes applied research and policy analysis on structural changes affecting the developing and transitional economies, provides a forum for the advocacy of policies leading to robust, equitable and environmentally sustainable growth, and promotes capacity strengthening and training in the field of economic and social policy making. Work is carried out by staff researchers and visiting scholars in Helsinki and through networks of collaborating scholars and institutions around the world.

www. wider.unu.edu publications@wider.unu.edu

UNU World Institute for Development Economics Research (UNU-WIDER)

Katajanokanlaituri 6 B, 00160 Helsinki, Finland

Typescript prepared by Lisa Winkler at UNU-WIDER

The views expressed in this publication are those of the author(s). Publication does not imply endorsement by the Institute or the United Nations University, nor by the programme/project sponsors, of any of the views expressed. 


\section{Introduction}

Diagnostically, the paper revolves around the concept of non-state sovereign entrepreneurs. We first focus on the concept of the sovereign, particularly the sovereign state, inasmuch as it relates to local and global governance and, in turn, pertains to violent social conflict. Finding that state sovereignty lies at the crux of the inability to deal with violent social conflict in a timely manner, we then shift our attention to consider a different solution approach, namely that of non-state sovereign actors and the entrepreneurship required to form non-territorial sovereign organizations that might address violent social conflict effectively, efficiently, and reliably.

The next section discusses varieties of entrepreneurship, followed by a section that contains a diagnosis of why violent social conflict proves hard to contain under current state-based arrangements. The new foundational concepts of non-state sovereign entrepreneurs (NSEs) and the non-territorial sovereign organizations they form (NSOs), emphasize the difference between these organizations and non-governmental organizations (NGOs) are discussed. The section also provides and discusses a number of historical and contemporary examples of NSOs. The last section summarizes and concludes.

\section{Varieties of entrepreneurship}

\subsection{Commercial entrepreneurship, political entrepreneurship}

Entrepreneurs are more easily named than defined-for the United States, one 20th century list includes Bill Gates (Microsoft), Sam Walton (Wal-Mart), Ted Turner (CNN), Henry Ford (Ford Motor Company), Ray Kroc (McDonald's and franchising), and Fred Smith (FedEx) — but one way or another character attributes such as envisioning and pursuit of commercial market opportunities, provision of leadership, and risk assumption are mentioned. Entrepreneurs do not need to start from scratch (Ray Kroc took over someone else's business and then built it up), be singular (Bill Gates' quieter co-founder of Microsoft was Paul Allen), or become multibillion dollar businesses.

Risk-taking as a character trait of entrepreneurs has been traced to Richard Cantillon (ca. 1730) but the precise term appears to originate with Jean-Baptiste Say (1803, Book I, Chapter V) who applies it to a person who sees market opportunity by combining capital and labour that are not necessarily his own. Joseph Schumpeter (1942) extended this to one who sees opportunity in a particular kind of innovation, namely one that competitively destroys fellow businessmen's markets by offering superior products or services for sale. Hence the celebrated phrase 'creative destruction'. Even better, instead of merely creating an improved water mill, gas lamp, or card catalogue, the invention of 'disruptive technologies', such as steam power, electric lights, or modern-day information technology, created entirely new industries from scratch (a process The Economist calls 'creative creation'). 1

1 On the term entrepreneur, see e.g., Sobel (2007) or the Wikipedia entry. On entrepreneurship, also see the extensive survey in The Economist magazine (12 March 2009) and the sources cited there. 
Whereas the entrepreneur is an agent of change, entrepreneurship refers to a process, and, at least since Schumpeter, much thought has been given to governmental policies that would condition the economic environment so as to enable this process to function with minimal friction and call forth the agents on demand. 2 If economy-wide growth and subsequent prosperity are driven by entrepreneurship, then the proper role of government lies in providing a nurturing institutional environment such as minimalist, and unbiased, regulation, a stable legal framework, and sound money. In economic theory this has led to the formulation of new theories of economic growth (e.g., Romer 1990). But the empirical literature that aims to causally and precisely relate Schumpeterian entrepreneurship to economic growth-to link micro activity to macro outcomes_-remains unsettled, certainly for developing economies.

Usually confined to commercial society, it is recognized that the attributes of entrepreneurship carry over to other fields such as political, social, religious, and academic entrepreneurs. ${ }^{3}$ In addition to goods and services, certain agents in society produce 'bads' and 'disservices'. Entrepreneurs and entrepreneurship can be productive or unproductive, or even destructive (e.g., Baumol 1990).

Paraphrasing The Economist, one also might speak of 'destructive destruction'. Specifically with respect to war and other violent social conflict, social scientists such as Kenneth Boulding, Jack Hirshleifer, and Gordon Tullock developed concepts such as contest success functions and appropriation and coercion-based economics (as compared to production and exchange-based economics), and the toolkit of neoclassical economics is applied to phenomena such as rent seeking, organized crime, rebellion and revolution, civil war, and terrorism. More recently it has been broadened further and is labelled security economics. The now voluminous literature of economics and quantitative political science provides evidence of both micro and macroeconomic causes and consequences of destructive political entrepreneurship. 4

\subsection{Social entrepreneurship, sovereign entrepreneurship}

A third type of entrepreneurship is seen in the profit and not-for-profit (non-taxed) social entrepreneurs who necessarily combine commercial with sociocultural or sociopolitical aspirations. Prominent examples include Amnesty International, Greenpeace, International Alert, Global Witness, and Doctors Without Borders, each of which, in one way or another, deal with violent social conflict and whose presence in or

2 By analogy, if the entrepreneur is the spark, then workers and managers serve as engine and oil, respectively, in the machinery of economics.

3 We use the phrase commercial society as an alternative to the more common term business. Commercial society consists of private sector commercial operations of all types and their collective organizations such as Chambers of Commerce and labour unions who do not fit well within the rubrics of civil society or government. However, when chambers of industry or labour unions are staffed by government appointment and funded through mandated taxes we would classify them as part of government. This would also apply to state-owned enterprises that operate at fiat prices rather than market prices.

4 Destructive political entrepreneurs may just be failed constructive entrepreneurs. Had the English King's forces won, would we not today regard George Washington as a failed entrepreneur? On security economics, see e.g., Brück (2005); Brück et al. (2008); Brauer and van Tuyll (2008, especially chap. 3 and 8). 
absence from conflict zones can make a drastic difference to the affected populations. All need to raise revenue, and all need to control cost so as to maximize resource flow toward their respective missions. At the same time, all were started by one or more persons with an entrepreneurial vision. All innovated and created a market, yet we are not aware of much scholarly attention having been given to them in the conflict literature.

The Skoll Centre for Social Entrepreneurship at Oxford University's Saïd Business School defines social entrepreneurship as 'the product of individuals, organizations, and networks that challenge conventional structures by addressing failures_-and identifying new opportunities - in the institutional arrangements that currently cause the inadequate provision or unequal distribution of social and environmental goods'. One way of phrasing this - if only for emphasis - is to say that instead of a commercial entrepreneur also delivering, in an Adam Smithian world, unintended public benefits, social entrepreneurs aim to deliver public benefits that also yield non-incidental private benefits to them. 5 In contrast to foundations (e.g., Rockefeller, Ford, or Gates) which are funded by endowment, today's social entrepreneurs stake their own economic livelihood on their ability to raise money and sell a 'social' product or service. And under the motto of 'doing well by doing good', a number of today's efforts are even organized along profit lines. 6

In addition to commercial, political, and social entrepreneurship, a fourth type is sovereign entrepreneurship. It is well-known that states offer different baskets of services at different prices (tax rates). So long as freedom of movement (migration) is guaranteed, people and corporations sort themselves into jurisdictions-sovereigntiesof their choice based, in part, on the particular mix of services and costs a sovereign provides. 7 For example, some Caribbean states are favourite offshore locations for financial firms, and due to more flexible operating conditions and tax structures, shipping companies are flagged in Liberia or Panama. Likewise, states compete for skilled workers generally (e.g., Canada, Australia, New Zealand) or for particular skills specifically (e.g., in health services). Within and between states, jurisdictions advertise communal amenities, natural beauty, cultural offerings, educational opportunities, or restful quietude. Others offer effective, efficient, and reliable commercial regulation. Entities such as Hong Kong and Dubai have been entrepreneurial in carving out specific roles for themselves in the international market place.

Some see this type of sovereign competition as a threat to sovereignty, while others believe that this type of competition can motivate sovereigns to provide better governance (van Veen 2007). There is no doubt that a sovereign who wishes to attract foreign resources will need to forego more policy options than one that is unconcerned about attracting foreign resources. As closed North Korea and open Singapore show,

5 Indeed, in addition to intended public benefits they may also deliver unintended public benefits, for example, when better health care provision directly benefits not only the affected population but also their employers.

6 There are several foundations whose mission it is to bring social entrepreneurs into being. Among them are the Ashoka, Schwab, and Skoll Foundations (see for example: Skoll: www.sbs.ox.ac.uk/skoll). None as yet appears to have set up a social entrepreneurship incubator.

7 See Tiebout (1956). 
sovereigns are free to make that choice. However, there is nothing in the international system that shields them or their citizens from the consequences of their choices. Sovereigns should not expect to have absolute autonomy and still enjoy international insurance against making poor choices. Rather, the question is whether a sovereign's subjects may have that expectation or even the right of insurance against sovereign failure, a complex set of issues to which we now turn.

\section{Failed governance and the sovereign prize}

\subsection{The sovereign state: attributes and purposes}

Today, sovereignty refers to self-rule of a people in a given territory; however that rule might be culturally sanctioned and operationally exercised. The present international system consists of an assemblage of self-ruling sovereignties that has its origin in the 1648 Peace of Westphalia. A modern sovereign state takes on (at least) three fundamental attributes:

1. The sovereign has legitimate authority: authority is acknowledged power and not just the potential use of coercive force. The sovereign derives authority from some legitimizing source, which can be either/both internal (often ideological) and external (recognition by other sovereigns).

2. The sovereign has supremacy: there is no authority above a sovereign, and all authority within the sovereign's realm is inferior to it.

3. The sovereign has territory: a state is defined as supreme within its territory.

Sovereigns, being supreme within their territory, operate as de jure equals to each other. Interactions between territories remain the exclusive domain of sovereigns. They can encourage, discourage, or prohibit such interactions. No institutions above them exercise legitimate, binding authority. 8

The central purpose of such sovereignty is to facilitate governance within the realm, that is, to establish rules, laws, regulations, and enforcement mechanisms. State-based governance is called government and comprises legislative, executive, and judicial aspects. Non-state forms of governance exist alongside the state. Every family and firm has its own procedural and behavioural norms and rules and formal or informal enforcement mechanisms. 9 Families and firms are governed societies without the accoutrement of statehood. For example, nomadic tribes used family relationships to establish the first governed societies without a fixed relationship to territory. Some of these societies still exist today, and sometimes in conflict with Westphalian states.10

8 Even interstate organizations like the UN are not above this authority due to the voluntary nature of such institutions. That sovereign states exist outside of and even withdraw from these organizations demonstrates that sovereignty continues to reside within the sovereign state in interstate organizations. Sovereigns only relinquish de jure sovereignty when they choose to do so.

9 State and non-state governance interact. For example, labour law circumscribes what a firm may or may not do in regard to its workforce and family law sets strictures on how parents deal with their children. Similarly, civil and commercial activity can filter through and influence state-wide lawmaking, especially in democracies.

10 The Roma in Europe and the Bedouin in Kuwait/Saudi Arabia are examples of nomadic peoples who have been discriminated against by states. As recently at 1993 between 10,000 and 25,000 Roma lost 
Similarly, religions exercise authority over the faithful based on their beliefs, not their geographic home. Empires extended some degree of authority over territories where they had large commercial interests. Thus empire-wide laws applied to individuals recognized by the centre of the empire, but vassal lords often held legal sway over local populations. In all these non-state cases, attributes one and two of modern day sovereignty tend to hold-i.e., authority and supremacy (certainly for firms, less so for modern families) - but attribute three in particular (defined territory) does not.

Externally, sovereigns can voluntarily form or join institutions by mutual agreement with other sovereigns and put limitations on their behaviour. The United Nations is one such treaty organization. Being voluntary, withdrawal from membership is possible and thus sovereignty is maintained. The Charter of the United Nations and a series of declarations, resolutions, and concrete acts associated with post-Second World War decolonization simplified and strengthened the concept of sovereignty, particularly with regard to a sovereign's absolute control over a defined territory.

The United Nations General Assembly's Friendly Relations Declaration of 24 October 1970 states that 'no State or group of States has the right to intervene, directly or indirectly, for any reason whatsoever, in the internal or external affairs of any other State'.11 The non-interference model of state sovereignty is a foundational part of today's international legal framework. Indeed, Article 1(1) of the International Covenant on Civil and Political Rights states as the first human right that 'all peoples have the right of self-determination. By virtue of that right they freely determine their political status and freely pursue their economic, social, and cultural development'.12 The sovereign state has been the principal means by which global society has implemented the principle of self-determination.

Non-interference of one sovereign in another's affairs is a prerequisite for selfdetermination and thus for the realization of all the other rights and values a community seeks. As seen in the Charter of the United Nations, the Westphalian system demonstrates a belief that armed interventions are almost always predatory in nature. Therefore, the principle of state sovereignty now largely operates to protect weak states from predation by the strong, hence the vociferous resistance by some states to the United States's war started in 2003 against Iraq and the equally determined resistance by states to grapple effectively and decisively with cases such as Sudan and Zimbabwe. Thus the purpose of external state-to-state voluntary, mutual agreements also is governance, in this case the governance of state-to-state relations within the international system of sovereign states.

their Czech citizenship because, being nomadic, they could not meet the residency requirements set by the Czech Republic when it separated from Slovakia.

11 See UN General Assembly, Declaration of Principles of International Law Concerning Friendly Relations and Co-operation Among States in Accordance with the Charter of the United Nations, 24 October 1970. Available at: www.unhcr.org/refworld/docid/3dda1f104.html. Adopted by General Assembly resolution 2625 (XXV) of 24 October 1970.

12 International Covenant on Civil and Political Rights, G.A. res. 2200A (XXI), 21 UN GAOR Supp. (No. 16) at 52, UN Doc. A/6316 (1966), 999 U.N.T.S. 171, entered into force 23 March 1976. See www1.umn.edu/humanrts/instree/b3ccpr.htm. 


\subsection{Incentive problems of state-based governance}

Although the legal framework for sovereignty is contemporary, that does not mean that sovereigns operate today unambiguously within that framework. Nor does it mean that such a framework, focused on the state as the sole legitimate actor in international relations, provides a sufficient foundation for effective, efficient, and reliable global governance.

For example, the lack of concern for sovereign responsibility once sovereign rights have been captured has become a contentious issue. Today it is widely accepted by global civil society that a sovereign should be the agent of its people, individually or communally. When people confer rule making power on an agent, they confer rights to speak and act on behalf of the collective, and that right is conferred with an understanding that the sovereign will act in their collective interest and for their benefit. But these rights can and often are usurped, not only but especially in multitribe or multination states when one group wishes to assert rights over one or more of the others by dent of grasping the reins of, and therefore the international protection granted to, statehood. In the absence of countervailing political, cultural, and commercial institutions within or outside the state, the absolute power granted to a sovereign encourages the abuse of sovereignty. Usurpation of power is facilitated and enhanced when other sovereigns in the Westphalian system accept their obligation not to intervene. Consequently, successful political entrepreneurs are generally welcomed into the fold so long as they do not directly threaten the interests of other sovereigns.

Former Australian foreign minister Gareth Evans characterizes the acceptance of internal state violence by other states under the Westphalian system as the 'institutionalization of indifference', and cites former US American Secretary of State Robert Lansing as remarking, in conjunction with his role as a member of the Paris Peace Treaty negotiation team in 1919, that 'the essence of sovereignty is the absence of responsibility' (Evans 2008: 18). Sovereignty is synonymous with immunity from outside discipline. No matter how horrific the process of usurping state power or of putting opposition movements down, a sovereign state can rightfully expect the inaction of other sovereigns. Although vigorously keeping an external balance of power between and among each other, sovereigns under the Westphalian system grant each other an internal monopoly on violence, even to the extent of granting an effective right to rule through violence, oppression, or rigged elections.

This grant amounts to a priori immunity from prosecution for even the most blatant immoral and inhumane treatment of a state's subjects. It also amounts to an incentive for internal opponents to organize coup d'états, assassinations, or insurrections to seize the reins of sovereignty. Sovereignty is contestable and offers a lucrative winner-takeall prize, namely the sovereign right of absolute control over territory, its entire people, and all other resources within. The (bloody) contest for the prize of sovereignty stems from such grand power.

Driving this contest is the fact that once won, other sovereigns tend to accept the winner as a legitimate sovereign into the international community of states with little concern about the legitimacy of the contest or of the regime itself. Rather than encouraging selfdetermination, sovereignty in some places has allowed the victor the ability to harass and even destroy peoples within its territory. The state's monopoly on violence, combined with the principle of non-interference, give the sovereign an incomparable 
edge in any domestic dispute. In essence, any sovereign is acceptable to other sovereigns, no matter how that sovereignty has been come by and sustained.

\subsection{The Westphalian obstacle}

Even when limited to the realm of human security, an increasing number of issues are challenging the basis of the Westphalian system and demand behaviours that are contrary to Westphalian doctrines. A sampling of them includes the following:

- Global civil society now widely agrees that some state behaviours are so outrageous as to constitute intolerable crimes against humanity and require that limits be placed on Westphalian sovereign immunity. The Responsibility to Protect (R2P) movement asserts that if a sovereign can not or will not protect its own subjects from mass atrocities then it is the responsibility of other sovereigns to protect them, even if that requires armed intervention. This violates a number of sovereign rights, among them the right to monopoly on the use of force, the inviolability of territory, control of borders, and suzerainty over citizens. 13

- The recently established International Criminal Court in The Hague is meant to begin to overcome some of the inadequacies of the Westphalian system. It required a great deal of effort to establish, largely due to the fear of state sovereigns of the development of a suprastate authority. Consequently, only citizens of sovereigns who agree to be bound by ICC jurisdiction may be tried under its authority (or any person committing a crime in a state that has acceded to the ICC Statutes). This limits the ability of the court to prosecute specific cases. The ICC is further restrained in that by a majority vote of the United Nations Security Council sovereign states may prevent the prosecution of a specific case, and any veto in the Security Council can stop an intended ICC prosecution. 14

- Non-state military and criminal organizations are increasingly challenging the system of international relations. Sovereign states that do not or can not wholly control their territory, such as tribal areas in Pakistan, nevertheless are held responsible for the activities that go on there. Other sovereigns, feeling threatened by those activities, may seek retribution against the incapable sovereign and/or may violate international norms through direct intervention,

13 On the history of R2P see www.responsibilitytoprotect.org. Although initiated with the support of some states, the R2P project is civil society-based. Notwithstanding claims on the R2P web site that all governments have 'endorsed' R2P, the text of the relevant United Nations General Assembly resolution (UNGA A/60/L.1*, 20 September 2005, §§138-40) is put in the usual careful, diplomacy language. In the end, $\S 139$ is quite clear that, as before, any non-peaceful intervention is left up to a resolution of the United Nations Security Council on a case-by-case basis.

14 See http://untreaty.un.org/cod/icc/statute/romefra.htm, Article 16: 'Deferral of investigation or prosecution. No investigation or prosecution may be commenced or proceeded with under this Statute for a period of 12 months after the Security Council, in a resolution adopted under Chapter VII of the Charter of the United Nations, has requested the Court to that effect; that request may be renewed by the Council under the same conditions'. 
risking war in the process. 15

- Even in the presence of international treaty obligations, prohibitions in regard to weapons of mass destruction (WMD) are difficult to monitor and enforce due to policy independence and sovereign control over territory. Thus only limited enforcement mechanisms are incorporated into WMD treaties due to these concerns. Technology has made WMD much more destructive, and deliverable, than the weapons of 400 , or even 50 years ago. The Westphalian system has not developed a structure to deal effectively with imminent, anticipated, or potential threats. Such systems are needed or individual states will assert their sovereign rights to self-defence, as the United States has done, in potentially premature, chaotic, and dangerous ways.

- Interstate wars are the ultimate dispute settlement method under the Westphalian system. Because states are the highest form of political authority, only interstate armed violence can solve disputes where at least one state is unwilling to accept negotiation or moral persuasion, as is a sovereign's right. The reliance of the Westphalian system on military power and war as the ultimate arbiter is inherently at odds with the strong desire of most people to make law and proper governance the ultimate arbiter.

These are but a sample of issues—-pertaining to violent social conflict — the resolution of which is impeded by the Westphalian system and the current norms of state-based governance. Westphalia is the obstacle. It is imperative that we recognize that dependence on sovereign states is no longer meeting the needs of diverse societies on Earth.16 It is not meeting peoples' needs within the state, nor is it maintaining appropriate relations between and among them, nor does it facilitate effective governance of crucial global issues.

Along these lines Stephen Krasner of Stanford University refers to sovereignty as 'organized hypocrisy' (Krasner 1999). Similarly, Andreas Osiander calls it the 'Westphalian Myth' (Osiander 2001). More than 20 years ago, Daniel Bell, a Harvard sociologist, noted that the 'nation-state is becoming too small for the big problems of life, and too big for the small problems of life' (Bell 1987: 14). Professor Louis Henkin, a Columbia University specialist in international law, was even more critical. He wrote that:

'[Sovereignty's] birth is illegitimate, and it has not aged well. The meaning of sovereignty is confused and its uses are various, some of them unworthy, some even destructive of human values... The pervasiveness of that term is unfortunate, rooted in mistake... Sovereignty is a bad word, not only because it has served terrible national mythologies; in international relations, and even in international law, it is often a catchword, a substitute for thinking and precision...for legal purposes, at least, we might

15 Relatedly, the high seas fall under no one's sovereignty. And yet there are increasing problems. Nearshore piracy is covered as near-shore areas fall within sovereign jurisdictions, but high seas areas do not.

16 Most of the extant forms of global governance are based on arrangements by and for states. Treaty organizations such as the United Nations system, WTO, NATO, ASEAN, and the AU only admit states to membership and are held hostage to sovereign interests rather than to the common interests of the global community, the peoples and their environment as a whole. On the AU, see Kioko (2003). 
do well to relegate the term to the shelf of history as a relic from an earlier era... As applied to a state, elements long identified with 'sovereignty' are inevitably only metaphors, fictions, fictions upon fictions'.17

These are but a sample of the extensive number of writers and practitioners gravely concerned about the consequences of continuing to meet the need for effective, efficient, and reliable global governance of serious global issues utilizing a sovereign state-based model of international relations. As global governance exceptions proliferate and as more issues are at odds with the system of state actors, it appears that these occurrences are linked to an underlying cause: the inherent inability of the Westphalian system to guide humankind in creating effective, peaceful, and just global institutions of governance. Another approach, or at least an alternative, parallel, or complementary approach, is needed.

\section{Non-state sovereign entrepreneurship}

In our view, the problems of local or global governance, including violent conflict within and between states, can be ascribed not merely to the faulty exercise of state sovereignty but to its very existence. Whatever proximate solutions are proposed, such as R2P civil society engagement which defers to the United Nations Security Council or the UN Global Compact which seeks to harness commercial society under a United Nations umbrella, ultimate solutions must address the restoration of effective, efficient, and reliable governance and legitimate sovereignty beyond the state.

Ultimate solutions must address the creation of what we term Inclusive Governance Networks (IGNs), or effective, efficient, and reliable governance and legitimate sovereignty beyond the nationstate, characterized by the inclusion of commercial and civil society, alongside government, as legitimate sovereign actors. Yet, virtually the entire academic and public discussion regarding global governance carries the terms of reference of the Westphalian-type, United Nations, state-based system. But unlike global civil and commercial society, the members of that system are, ironically, the least global players. They can not but act with parochial interests in mind. Thus, due to its design, state-based global governance is unlikely to succeed.

What is needed is an enforceable, rules-based global structure that elevates the legitimate role of civil and commercial society. Sovereigns must exist in the pre-1648 sense: universal assertion of authority and supremacy, but non-territorial—or encompassing territorial, that is, global. Like what the Roman Church once thought it was-universal, free from parochial interests, with governance exercised through increasingly local nodes-effective global governance will only come though the expansion of legitimate roles for civil and commercial societies within appropriate issue domains.

The question arises of how this can possibly be achieved today? Our suggestion looks to NSE and increased legitimate space for NSOs. NSE deals with the rise of transboundary non-state actors as they impinge on and aim to supplement and supersede certain

17 Krasner (1999); Osiander (2001); Bell (1987: 14); Henkin (1999, as cited by Linde 2006: fn. 235; and Henkin 1995: 8-10). 
powers of sovereign states. Global civil and commercial society must engage in the innovative search for and operation of sovereign, that is, rule making and rule enforcing yet non-state (non-territorial) powers.

\subsection{Non-state sovereign governance already exists}

Even though the state predominates in international relations, an important observation is that there exist, and have always existed, a number of non-state governance structures, including global ones, that derive their coherence, effectiveness, and cultural legitimacy from identities based on non-national, non-state attributes. Religious beliefs offer one example. The Roman Catholic Church, or the communities of Jews or Muslims or other faith traditions, precede-and all territorially transcend-the sovereign state. Each asserts and exercises sovereignty over its respective spiritual domain. They formulate, promulgate, and enforce religious law upon their believers. They once claimed and severely enforced monopoly rights over their subjects' fealty, loyalty, and lives. Many adherents still fervently believe in, and identify with, the exercise of canonical rights even as competing forms of non-religious sovereignty have evolved. While the Vatican has diplomatic standing (since 1929), the leader of Tibetan Buddhism, the Dalai Lama, does not. In times past, the situation was reversed: to be viewed as legitimate, that is, sanctioned (blessed), leaders of secular entities needed formal recognition by heads of spiritual entities.

For many of today's world citizens, universal social movements, and global corporations, identification with nation or state has become nominal, even notional. To them, nationalism and statism are passé: the relevant scope (and sometimes identity) is their issue or their industry. Geographical territory, the very basis of the sovereign state, is decidedly less important to them than it once was. Many of these have achieved legitimacy through their expertise or operant values.

A striking commercial example of non-state sovereign global governance is provided by ICANN, the Internet Corporation for Assigned Names and Numbers. Its mission 'is to coordinate, at the overall level, the global Internet's systems of unique identifiers and in particular to ensure the stable and secure operation of the Internet's unique identifier systems'.18

Clearly, the scope of ICANN's activity is global, and it is the ultimate rule making body in designing and assigning internet domain names, a task that is vital to the stability of the internet. ICANN assigns domain name suffixes for states and territories such as Palestine, Hong Kong, Taiwan, and the Vatican (ps, hk, tw, and va, respectively), without consideration for their sovereign status. After the Assembly of Kosovo declared the Republic of Kosovo an independent sovereign state in February 2008, Kosovo used the World Economic Forum in June that year to appeal to be granted its own domain name suffix. ICANN deferred that decision to another non-state global governance organization, the International Organization for Standardization (ISO) which, according to its ISO3166-1 standard, makes the call as to what entities qualify for mail routing, currency, and other codes. As of 23 September 2008, Abkhazia, Transnistria, Somaliland, and South Ossetia also were on the list of would be recipients of their own

18 See www.icann.org/en/general/bylaws.htm\# 
DNS codes. Like Kosovo, all are, or recently were, embroiled in war.19 The domain name system (DNS) has become a symbol of statehood, yet it is granted by two nonstate actors.

ICANN is a private, non-profit, California-registered, public benefit corporation, operating under California law, not United States federal law. Governments have no direct decision making powers in the operations of ICANN. All powers are vested in ICANN's Board of 15 voting members. The majority of the Board members are selected by a Nominating Committee which seeks 'to ensure that the ICANN Board is composed of members who in the aggregate display diversity in geography, culture, skills, experience, and perspective'. Nationality or statehood are deliberately excluded. Moreover, 'notwithstanding anything herein to the contrary, no official of a national government or a multinational entity established by treaty or other agreement between national governments may serve as a Director'.

In the event of instability of the DNS, ICANN can form a crisis management team to determine what intervention it should take to ensure or restore stability to the system. It could credibly be argued that this is at least as critical to the world as is the stability of the telephone system. But the stability of the telephone system is controlled by the International Telecommunications Union (ITU), which is an intergovernmental treaty organization of the United Nations. While non-state actors may become associates, only state members have voting rights in the controlling organs of the ITU. The ITU is a prototypical Westphalian structure for interstate coordination and has a function for the telephone network that closely parallels ICANN's function for the internet.

Instead of civil and commercial society being accredited observers to an intergovernmental organization such as the ITU, ICANN literally inverts this familiar governance structure. Member governments each appoint one 'accredited' representative to ICANN's Governmental Advisory Committee (Art. XI, Section 2(1)e). The Governmental Advisory Committee then may select from its members a single nonvoting Board Liaison Officer (one of six such non-voting officers). In ICANN the private corporation takes on the voting role of the sovereigns in the ITU, and the sovereigns take on the non-voting observer status of 'sector member'. Yet the rules of ICANN are just as enforceable on the states as are the rules of the ITU. Because the state is no longer supreme, this governance organization can not be reconciled with the Westphalian concept of the sovereign state.

There is no inherent reason why the ITU should not have been able to exercise sovereign control over the internet. That it did not suggests that its governing structure was too slow to adapt to the emergence of a new globe spanning technology. Yet that technology still needed a way to organize itself or be organized, and ICANN emerged to provide reliable internet governance. It is legitimized by expertise, effectiveness, and shared values, not by a democratic process. 20

19 See http://blog.icann.org/?p=357

20 Another example of existing non-state global governance occurs when global markets adopt a state’s currency as if it were their own. From criminal networks to the global petroleum trade to independent countries such as Panama (since 1904), Ecuador (2000), East Timor (2000), and El Salvador (2001), the United States dollar has become de jure legal tender, yet the government of the United States has no direct power over these adoptions (hence we consider them non-state). The dollar is legal tender 
Once one starts looking, examples of existing non-state global governance with some degree of sovereign power can be multiplied. There is no question for instance that Microsoft Corporation's Windows operating system is, in effect, a non-state, sovereign, global governance standard. And Microsoft recently enforced the standard when it blocked pirated Windows software from operating properly in China.21 The company also has worked to have the various versions of Windows declared a global standard by global standard setting bodies, and this is important because these bodies are not states, nor associations of states (as shown later on). It is a common, but largely unrecognized, practice for non-state actors to engage in global norm formulation, standard setting, and rule making with self-regulation and self-enforcement: in other words to engage in nonstate sovereign global governance.

\subsection{Non-territorial sovereign organizations are not non-governmental organizations}

At this juncture, it is useful to highlight why organizations such as ICANN are not nongovernmental organizations but are non-territorial sovereign organizations. The key insight - the one that drives the entire paper-is that NGOs are subsumed under and subject to the state (or to their multistate organizations). Unlike NSOs, NGOs possess neither rule making authority nor supremacy. Amnesty International and Greenpeace are influential global civil society actors, but unlike NSOs they have no legitimate source from which they could derive rule making and rule enforcing authority, as they lack supremacy within their issue domain. Crucially, however, both NGOs and NSOs are non-territorial, transboundary organizations.

As a matter of logic, the taxonomy of organizations should be rewritten as follows:

- State organizations (territorial or boundary organizations)

o single state organization (e.g., any and all states)

0 multistate organization (e.g., EU, AU, ICAO, ITU, WTO) ${ }^{*}$

- Non-territorial organizations (non-state or transboundary organizations)

0 non-territorial non-sovereign organizations (the former NGOs)

- civil society organizations (e.g., Greenpeace)

- commercial society organizations (e.g., IATA, WTTC)*

- Non-state sovereign organizations (NSOs)

o civil society sovereign organizations (e.g., the International Committee of the Red Cross, the International Olympic Committee, FIFA, and other

even in two British dependencies: the British Virgin Islands (1959) and the Turks and Caicos Islands (1973). In addition, the dollar is de facto tender in many war-torn societies and tourist destinations around the world (e.g., Afghanistan, Cambodia, and Uruguay). Small non-EU European states (Vatican State, Monaco, and San Marino) have adopted the euro in consequence of currency unions with EU-member states, and Andorra, Montenegro, and Kosovo adopted the euro unilaterally, even as they are not EU members.

21 When pirated software is loaded, it activates an update function, and Microsoft then can, and has, interfered with the proper operation of the computers on which the pirated software was loaded.

ICAO = International Civil Aviation Organization, ITU = International Telecommunications Union, WTO $=$ World Trade Organization, IATA $=$ International Air Transport Association, WTTC $=$ World Travel, and Tourism Council. The first three are public sector, state-based organizations, the latter two are commercial sector, non-state, non-sovereign organizations. 
examples to be discussed)

o commercial society sovereign organizations (e.g., ICANN, ISO, and other examples provided later on)

\subsection{Non-state sovereign global entrepreneurship}

This seemingly anomalous non-state global governance example of ICANN is not unique. 22 Other examples of non-state groups involved in global sovereign governance include the following. All were driven by entrepreneurs, some specifically with the objective of stopping or mitigating violent social conflict.

- Undoubtedly, due to its role in the peace and security field, a non-state actor of great interest is what now is called the International Committees of the Red Cross and Red Crescent, founded in 1863. This movement consists of several components, the most pertinent of which is the International Committee of the Red Cross (ICRC). The key entrepreneur behind the ICRC was Henry Durant, a businessman. ICRC spawned the initial and subsequent formulation of international laws of war and international human rights. Originally concerned with the treatment of battlefield wounded soldiers, the ICRC played a central and essential role in the First Geneva Convention, the International Convention for the Amelioration of the Condition of the Wounded and Sick in Armed Forces in the Field. This treaty got sovereigns to recognize the principle that helping the wounded, on or off the battlefield, was to be regarded as a neutral act. Since that initial Convention in 1864, the ICRC has effectively pressured states to extend ICRC protections under the rules of war to include naval warfare, prisoners of war, and civilians. 23

- The position of organized religions and their manifest, secular organizations, such as the Roman Catholic Church has already been alluded to. Clearly they exercise global, sovereign governance functions, yet with the exception of Vatican State, they are non-state organizations. The Vatican showed its entrepreneurial spirit by becoming a state in 1929,24 but there is of course no

22 Nor is it without problems. As is well-known, the state of the People's Republic of China is overtly blocking selected internet signals. This is akin to non-state cell phone operators blocking transmission signals in states or (see note 22) to Microsoft blocking software from functioning in China.

23 Durant's four co-founders were Gustave Moynier, Dr. Louis Appia, Dr. Théodore Maunoir, and Henri Dufour. Durant and the ICRC received the Nobel Peace Prize on four occasions, in 1901, 1917, 1944, and 1963. The seven principles of the Movement are humanity, impartiality, neutrality, independence, voluntary service, unity, and universality. The full name of the International Red Cross is The International Red Cross and Red Crescent Movement (www.redcross.int). It comprises National Red Cross and Red Crescent Societies (the National Societies), the International Committee of the Red Cross, and the International Federation of Red Cross and Red Crescent Societies. See www.icrc.org.

24 In 1648, Pope Innocent X issued the Bull Zelo Domu Dei, in which the Vatican rejected the sovereign rights nascent states arrogated unto themselves in the Peace of Westphalia. The Bull says that 'all such provisions have been, and are of right, and shall perpetually be, null and void, invalid, iniquitous, unjust, condemned, rejected, frivolous, without force or effect, and no one is to observe them, even when they be ratified by oath’ (www.shsu.edu/ his_ncp/Thirty.html). Defeated, the Vatican made common cause and, today, enjoys the rights of sovereignty it once condemned, the only religion with a recognized head of state. It acquired statehood in 1929 under Pope Pius XI. Pope John Paul II revised the Vatican's constitution on 26 November 2000. Politically, it is a dictatorship. Translated from German, Article 1(1) of its constitution reads: 'As head of Vatican State, the Pope owns full legislative, executive, and judicial powers'. ['Der Papst besitzt als Oberhaupt des Vatikanstaates die 
question about the church's social mission of ministering to the poor, sick, wounded, and abandoned.

- Within commercial society, an important governing role is played by the ISO. The ISO is a private, non-profit organization composed of standards institutes nominally arrayed by states, but none are recognized, nor may they act, as representatives of states in any formal, official, or sovereign way. Moreover, while some state standards institutes are indeed official government entities, many are either wholly private or are public-private joint ventures. The ISO sets standards, and the world follows them, quite outside formal Westphalian channels. Currently, the ISO is working on a 'societal security' series of standards (ISO22300) and is conducting preparatory work on 'social responsibility' standards (ISO26000) that may directly address peace and security concerns. It is not inconceivable that, in future, it might formulate and promulgate a state sovereignty standard and that states can elect to be 'ISO certified', just as companies do now. 25

- Arguably one of the stronger non-state actors in the world is the Fédération Internationale de Football Association (FIFA), the world body that regulates the sport of football (soccer). Its position as the ultimate governing body over the world's most popular sport allows it to assert itself in the political affairs of sovereign states. One recent example comes from Europe, when the state of Poland sacked the entire board of Poland's national football association for what FIFA determined to be non-football related (political) reasons. FIFA was able to use the credible threat of barring the Polish national football team from upcoming World Cup qualifying matches to compel the Polish government to reinstate the board and its president. An examination of FIFA's website shows that this is no isolated instance. 26

Fülle der gesetzgebenden, ausführenden und richterlichen Gewalt'] (See www.vatican.va/vatican_city_state/legislation/documents/scv_doc_20001126_legge-fondamentalescv_ge.html). The Vatican is not a member of the United Nations but, by UN General Assembly resolution A/RES/58/314 of 1 July 2004, the Holy See 'shall be accorded the rights and privileges of participation in the sessions and work of the General Assembly and the international conferences convened under the auspices of the Assembly or its other organs of the United Nations, as well as in United Nations conferences as set out in the annex to the present resolution' (http://daccess-ddsny.un.org/doc/UNDOC/GEN/N03/514/70/PDF/N0351470.pdf?OpenElement).

25 State sovereigns might be held accountable through civil society recognition of an alienability of sovereignty from its territory or by withdrawal of external recognition if a sovereign fails to meet recognized social responsibilities. Many academic and non-profit organizations have created indices that measure aspects of sovereign performance. In this regard, an ISO Sovereign Rights and Responsibilities Standard may be achievable. Some arrangement for a civil sector-driven imposition of trusteeship or receivership upon a sovereign could be developed when sovereign performance standards are not met. In the past, sovereigns have attempted to operate state trusteeships or receivership programmes with limited success (Krasner 2004). Perhaps a non-state driven effort might be worth a try.

26 Recently FIFA has also begun to use its power to try to fight racism in Europe and elsewhere and has banned fans from home games as penalties for racist chants. Given the 'national' identification and passion the game can arouse, it is extraordinary to note how (nation) states are compelled to submit to FIFA rulings. In addition, although the current discussion of limiting the number of 'foreign' nationals playing in 'national' club teams may, if implemented, violate EU labour laws, the very fact that such a discussion can be conducted in all seriousness demonstrates the considerable non-state sovereign global governance powers that FIFA holds. 
Examples of non-state sovereign global governance entrepreneurship are numerous. In addition to ICANN, ICRC, ISO, and FIFA, one may consider:

- The International Union for the Conservation of Nature and Natural Resources (IUCN) is an environmental organization and, like the ISO and ICRC, a private institution with huge influence on environmental and related state laws and regulations. To appreciate the example, compare it to certain EU laws that need state ratification. The EU is a state-based association; the IUCN is a non-state association. But in either case, top level rule making is filtered 'down' for local adoption. Thus the IUCN may very much be considered as fulfilling sovereign, rule making functions, with execution and enforcement delegated to states.

- Like FIFA, the Olympic Movement also is a private sports body with global rule making and enforcement powers. Interestingly, because of governance failures among Westphalian-type states it was a deliberate attempt at non-state peace making between and among states. The driving entrepreneur behind the Olympic Movement was Pierre de Coubertin, and its prominent symbol of the five interlocking, multicoloured rings that represent the (then) five continents is important inasmuch as the symbol rejects statism. It refers to people on land, not to subjects in states. 27

- The Kimberley Process Certification Scheme and VISA Inc. are other examples of global governance that are driven by non-state sovereign entrepreneurs, one coming off a global civil society movement that includes state and commercial participation, the other, like the Microsoft Corporation, coming off a purely global commercial undertaking. 28

- The International Accounting Standards Board (IASB) is a non-state academic and practitioner-driven body that sets global norms to which even the United States government (through the Securities and Exchange Commission) recently acceded.29

- The International Chamber of Commerce was founded in 1919 by an entrepreneurial Frenchman, Etienne Clémentel, and established its own International Court of Arbitration whose rulings are accepted by states. 30

- Medieval guilds set standards and enforced them, quite in the absence of states acting as governance bodies.

- Grounded in Islamic law, the informal money transfer network known as hawala is wholly based on trust and honour with presumably canonical but certainly not

27 Australia, in 1894, was not yet a separate state, at the time it consisted of six self-governing Crown Colonies, and Antarctica although known as an ice mass was not yet recognized as a separate landmass. On the Olympic Movement, its history, Charter, constituent bodies, and organization see multimedia.olympic.org/pdf/en_report_122.pdf

28 'The Kimberley Process (KP) is a joint governments, industry, and civil society initiative to stem the flow of conflict diamonds'. See www.kimberleyprocess.com. For a history of VISA Inc. see corporate.visa.com/about-visa/our-business/history-of-visa

29 See www.iasb.org/Home.htm.

30 See www.iccwbo.org and www.iccwbo.org/court. 
secular legal recourse in case of non-performance. 31

Although state consent may be involved in some cases of non-state sovereignty, states may not posses de jure or de facto veto over these entrepreneurial activities. If the membership of a World Consumers' Union for instance decided henceforth not to purchase product or service $\mathrm{X}$ from state $\mathrm{Z}$, there is nothing states could do about this. States, after all, are just one form of social organization, and if global civil society arranges itself in alternative, if simultaneous, ways then alternative modes of sovereign governance can evolve.

\section{Conclusion}

Stable and prosperous societies share three fundamental aspects. Their people are fully represented by their cultural, economic, and political institutions, in short, by civil society, commercial society, and political society (government). Civil society receives and allocates resources based on moral suasion. Commercial society receives and allocates resources through markets. Governments receive and allocate resources through power. Inclusive Governance Networks rely upon all three social realms and provide stability as each social realm resolves problems differently, supports and restrains the others, and is distinct but dependent on the others for long term legitimacy and continued functioning. 32

Civil and commercial societies have transcended state boundaries and now operate with global presence. There is nothing that intrinsically binds them to a single state. Only the state and its sovereign are intrinsically territorially bound and without global scope. That the earth is divided into entities that mutually recognize each other as sovereign states does not make any particular state global but instead emphasizes the division of the globe into insular states. Global governance, as currently practiced, is run by distinctly non-global players.

In this context, it is crucial to understand that our argument does not advocate the replacement of the sovereign state by civil and/or commercial non-state sovereign organizations. Instead, we propose that (1) presently, civil and commercial society are subsumed under, and subject to, the powers of a state-based system, (2) this social arrangement is at times dysfunctional and the root cause of the inability to address adequately local and global problems that are increasing in number and severity, and (3) to rectify these problems, the balance between and among civil, commercial, and political society needs to be realigned such that rule making and enforcement is no longer vested solely in the state.

Despite their powers of coercion, states do not have a monopoly on resources. Most of the accessible wealth in the world is held by the civil and commercial sectors of society.

31 As it was suspected of serving as a conduit for terror-related financing, hawala gained prominence in the wake of the 11 September 2001 attacks on the United States. The Western-style banking and finance sector of course also has served illicit purposes. Even when it is wholly legal, it still can run into global governance-related performance problems as the world economic crisis of 2008 and onward demonstrates. Meanwhile, hawala continues, as it must, because much of the world's population lives outside the formal, Western-style private and state banking sectors.

32 These are practical divisions of a unitary whole in which each person is involved in all three aspects: civic work, commerce, and governing. 
These resources could become available to support alternative local and global governance systems through a variety of fee-for-service arrangements. For example, if global airlines, tourism, and shipping industries did not have to carry the cost of numerous security provisions (e.g., defensive measures, higher insurance costs, foregone revenues), part of the cost saving could be charged as fees for the governance structures that reduced the risks. Unlike the British and Dutch East India companies, modern world corporations have no desire to raise and maintain their own armed forces. The new commercial empires like Accor, Allianz, Aramco, BHP Billiton, DeBeers, Embraer, Google, Herstal, Lenovo, Maersk, Mittal, Samsung, Tata, Toyota, or Vodafone, to name a few, easily possess the scope and reach of their colonial predecessors but without imperial sovereign ambitions. Today's corporate private security forces, whether in-house or contracted, are a necessary but otherwise unwelcome cost that corporations would rather not carry. Modern corporations do not wish to behave like state sovereigns; nor do they wish to maintain private military forces to ensure the security of their assets. Most are willing, even eager, to conform to local rules and regulations, and to have local sovereigns ensure the security of their assets and staff. Most just want to get on with business. To get their wish, more forward looking, entrepreneurially-driven action is required by business than is current practice or expectation and civil society should assist commerce rather than looking askance at it. Because peace reduces the cost of business and increases revenue, commercial society (i.e., business and business associations) can be encouraged to become constructive players in shaping an agenda for peace as part of their broader non-state global governance agenda. As demonstrated, there already exist many examples of commerce being engaged in state-transcending global governance structures, institutions, and organizations. This should also be applicable to the arena of peace and security worldwide.

\section{References}

Baumol, W. J. (1990). 'Entrepreneurship: Productive, Unproductive and Destructive'. Journal of Political Economy, 98 (5): 893-921.

Bell, D. (1987). 'The World and the United States in 2013'. Daedalus, 116 (3): 1-31.

Brauer, J., and H. van Tuyll (2008). Castles, Battles, and Bombs. Chicago, IL: University of Chicago Press.

Brück, T. (2005). 'An Economic Analysis of Security Policies'. Defence and Peace Economics, 16 (5): 375-89.

Brück, T., M. Karaisl, and F. Schneider (2008). 'A Survey on the Economics of Security’. Final Report for the European Commission, Directorate-General for Justice, Freedom and Security. Berlin: Deutsches Institut für Wirtschaftsforschung.

Cantillon, R. (ca. 1730). Essay on the Nature of Trade in General (translated from French). London: Fletcher Gyles.

Evans, G. (2008). The Responsibility to Protect: Ending Mass Atrocity Crimes Once and For All. Washington, DC: Brookings Institution Press.

Henkin, L. (1995). International Law: Politics and Values. Amsterdam: Martinus Nijhoff Publishers. 
Kioko, B. (2003). 'The Right of Intervention under the African Union's Constitutive Act: From Non-interference to Non-intervention'. International Review of the Red Cross, 85 (852): 807-25.

Krasner, S. D. (1999). Sovereignty: Organized Hypocrisy. Princeton, NJ: Princeton University Press.

— (2004). 'Sharing Sovereignty: New Institutions for Collapsed and Failing States'. International Organization, 29 (2): 85-120.

Linde, C. (2006). 'The U.S. Constitution and International Law: Finding the Balance'. Journal of Transnational Law and Policy, 15 (2): 305-39.

Osiander, A. (2001). 'Sovereignty, International Relations, and the Westphalian Myth'. International Organization, 55 (2): 251-87.

Romer, P. (1990). 'Endogenous Technological Change'. Journal of Political Economy, 98 (5): S71-S102.

Say, J. B. (1803). A Treatise on Political Economy, or the Production, Distribution and Consumption of Wealth. London.

Schumpeter, J. (1942). Capitalism, Socialism, and Democracy. New York, NY: Harper and Row.

Sobel, R. S. (2007). 'Entrepreneurship'. Entry in The Concise Encyclopedia of Economics. 2nd ed. Indianapolis, Available at: www.econlib.org/library/Enc/Entrepreneurship.html

Tiebout, C. (1956). 'A Pure Theory of Local Expenditures'. Journal of Political Economy, 64 (5): 416-24.

Van Veen, E. (2007). 'The Valuable Tool of Sovereignty: Its Use in Situations of Competition and Interdependence'. Bruges Political Research Papers. Bruges: College of Europe. 